\title{
Prolactin activation of mammary nitric oxide synthase: molecular mechanisms
}

\author{
F F Bolander Jr \\ Department of Biological Sciences, University of South Carolina, Columbia, South Carolina 29208, USA \\ (Requests for offprints should be addressed to F F Bolander Jr; Email: Bolander@sc.edu)
}

\begin{abstract}
Prolactin (PRL) is capable of stimulating both calcium and nitric oxide (NO) accumulation in mammary epithelial cells within $15 \mathrm{~min}$. A calcium ionophore was also able to stimulate NO levels to an extent similar to that generated by PRL. Furthermore, maximal concentrations of PRL and the ionophore were not additive, suggesting that they were both using the same pathway, i.e. calcium. Finally, the depletion of intracellular calcium completely abrogated the effect of PRL on NO production. No other pathway known to affect NO synthase (NOS) influenced the action of PRL. Specifically, manipulations of protein phosphatase $2 \mathrm{~B}$, protein kinase $\mathrm{B}(\mathrm{PKB})$, protein kinase $\mathrm{C}$ (PKC), and arginine transport did not alter the activation of NOS by PRL. Therefore, the ability of PRL to stimulate NO production at 15 min can be completely explained by its ability to elevate intracellular calcium.
\end{abstract}

Journal of Molecular Endocrinology (2002) 28, 45-51

\section{Introduction}

In mouse mammary epithelial cells, prolactin (PRL) transiently elevates nitric oxide (NO), which enhances DNA synthesis and recruits PRL receptors from internal membrane pools to the cell surface (Bolander 2001). The purpose of this study is to determine the molecular mechanisms by which PRL activates the NO synthase (NOS).

Acutely, NOS is activated by elevated calcium levels both directly via calmodulin and indirectly via stimulation of protein phosphatase $2 \mathrm{~B}$, which dephosphorylates the enzyme at inhibitory sites. Protein kinase $\mathrm{B}(\mathrm{PKB})$ can stimulate NOS by phosphorylating it at alternate sites (Dimmeler et al. 1999, Fulton et al. 1999). Finally, in most cells arginine, the substrate for NOS, is limiting and NOS can be activated by increasing arginine uptake (Dodd et al. 2000). Prolactin has the potential to affect all of these pathways (Fig. 1): it can elevate calcium levels (Bolander 1985) and stimulate both arginine transport (Rillema et al. 1992) and PKB activity (Al-Sakkaf et al. 2000, Tessier et al. 2001).

\section{Materials and methods}

\section{Materials}

Ovine PRL (oPRL-19) was kindly provided by the National Hormone and Pituitary Program, NIDDK (Bethesda, MD, USA), and verapamil was a gift from Knoll Pharmaceutical Co. (Whippany, NJ, USA). Hepes, lysine, glutamine, ethyleneglycol-bis-( $\beta$-amino-ethylether)-N,N'-tetraacetic acid (EGTA), phorbol 12-myristate 13-acetate (TPA) and BSA were purchased from Sigma Chemical Company (St Louis, MO, USA). A23187, calphostin C, KN-62, and wortmannin were obtained from Alexis Corporation (San Diego, CA, USA); and cyclosporin A was from Calbiochem-Novabiochem Corporation (La Jolla, CA, USA). Phosphatebuffered saline (PBS), Medium 199 with Earle's salts, and Minimum Essential Media (MEM) Select-Amine Kit were purchased from Life Technologies (Rockville, MD, USA). Collagenase, type I (179 U/mg) was obtained from Worthington Biochemicals (Freehold, NJ, USA); and the Nitric Oxide Assay Kit was from AnaBioKit Ready2US, Inc. (Montreal, Canada). ${ }^{45}$ Ca-labeled $\mathrm{Cl}_{2}(30 \cdot 8$ $\mathrm{mCi} / \mathrm{mg}$ calcium) was purchased from ICN (Irvine, 


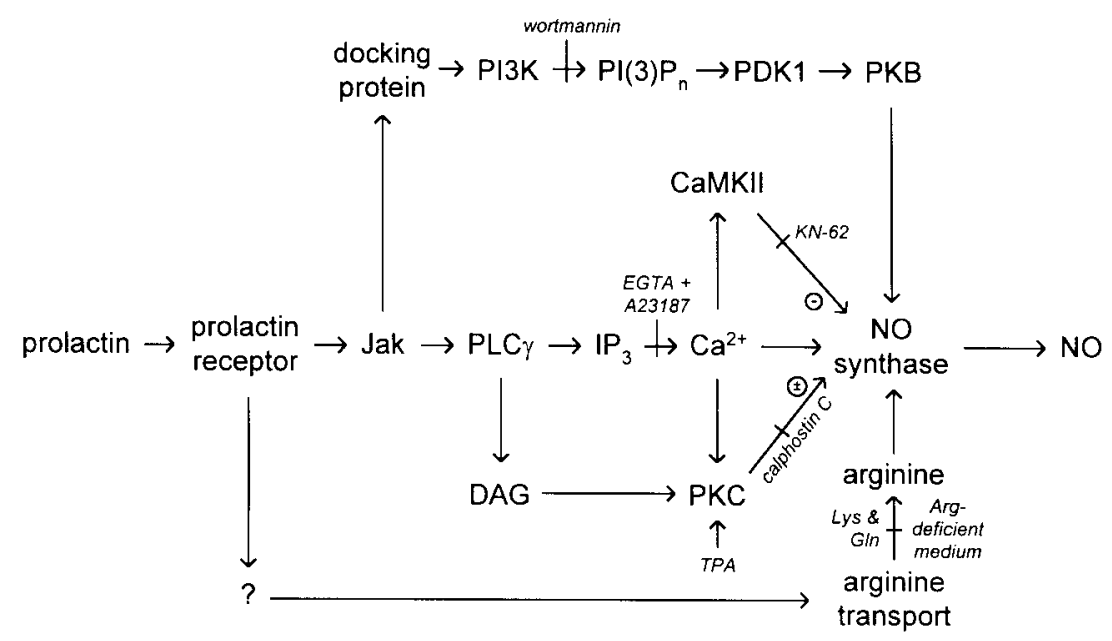

Figure $1 \mathrm{~A}$ scheme illustrating the possible mechanisms by which PRL could activate NO synthase and the location where various compounds used in this study act. DAG, diacylglycerol; PDK1, phosphatidylinositol-dependent protein kinase 1; $\mathrm{PI}(3) \mathrm{P}_{\mathrm{n}}$, phosphatidylinositol 3'-phosphate; $\mathrm{PLC} \gamma$, phospholipase $\mathrm{C} \gamma$; PP2B, protein phosphatase 2B; TPA, a phorbol ester.

CA, USA), and [methoxy- $\left.{ }^{3} \mathrm{H}\right]$ inulin $(452 \cdot 1 \mathrm{mCi} / \mathrm{g})$ were obtained from New England Nuclear Corp. (Boston, MA, USA).

\section{Cell culture}

Virgin mice $(\mathrm{C} 3 \mathrm{H} / \mathrm{HeN})$ were obtained from the Frederick Cancer Research Facility (Frederick, MD, USA). The mice were killed by cervical dislocation and an epithelial cell-enriched fraction was isolated from mammary glands, as previously described (Vonderhaar et al. 1973). Cells were cultured at $37{ }^{\circ} \mathrm{C}$ in Medium 199 containing $20 \mathrm{mM}$ Hepes (pH 7.6) and combinations of the following reagents, as required by the individual experiment: A23187 (32.5 nM) and EGTA $(3 \mathrm{mM})$ for calcium depletion, calphostin $\mathrm{C}$ $(100 \mathrm{nM})$, cyclosporin A $(100 \mathrm{nM}), \mathrm{KN}-62(10 \mu \mathrm{M})$, verapamil $(30 \mu \mathrm{M})$, and wortmannin $(100 \mathrm{nM})$. After $15 \mathrm{~min}$, PRL (100 ng/ml), A23187 (without EGTA) for calcium elevation $(32.5 \mathrm{nM})$ and/or TPA $(1 \mathrm{ng} / \mathrm{ml})$ were added to the appropriate cultures and the cells incubated for an additional 15 min. Cultures with TPA also contained BSA $(4 \mathrm{mg} / \mathrm{ml})$ to prevent the adsorption of TPA to vessel surfaces (Martel et al. 1983). The optimal concentrations of PRL, A23187, TPA, and verapamil were determined by dose-response curves (Bolander 1985, 2001, Caulfield \& Bolander
1986). The 15-min incubation was chosen as the optimal sampling point from a previously published time course (Bolander 2001). Protein kinase inhibitors were used at concentrations that were 5-10 times their $\mathrm{IC}_{50}$ (Davies et al. 2000).

Experiments designed to test whether arginine transport was important for early NOS stimulation either used Medium 199 containing $20 \mathrm{mM}$ Hepes $(\mathrm{pH} 7 \cdot 6)$, glutamine $(5 \mathrm{mM})$, and lysine $(5 \mathrm{mM})$ or used MEM containing $20 \mathrm{mM}$ Hepes (pH 7.6) but without arginine. As above, cells were pre-incubated for 15 min before PRL was added.

\section{Calcium accumulation}

Since it has been shown that the initial elevation of calcium evoked by PRL arises from the influx of calcium (Alfonso et al. 2001), calcium accumulation was determined by measuring the uptake of ${ }^{45} \mathrm{Ca}$ from the medium. Mammary explants were cultured in $3 \mathrm{ml}$ medium containing ${ }^{45} \mathrm{Ca}(10 \mu \mathrm{Ci} /$ $\mathrm{ml})$ and $\left[{ }^{3} \mathrm{H}\right]$ inulin $(5 \mu \mathrm{Ci} / \mathrm{ml})$. After $15 \mathrm{~min}$, the explants were weighed, washed twice with $3 \mathrm{ml}$ of medium without hormones followed by two washes with PBS. The tissue was dissolved in $0.6 \mathrm{ml}$ of a tissue solubilizer and counted in a scintillation cocktail. $\left[{ }^{3} \mathrm{H}\right]$ insulin was used to correct for ${ }^{45} \mathrm{Ca}$ trapped in the extracellular space. 


\section{NO assay}

Cytoplasmic NO was measured using the Nitric Oxide Assay Kit, which estimates NO from the concentrations of nitrate and nitrite, using the Griess reagent. NO production was expressed as a function of cell protein, as determined by the method of Lowry et al. (1951) using BSA as standard. Each dose-response curve required cells isolated from the glands of 15 mice.

\section{Experimental rationale}

In order to examine how PRL might stimulate NO production, one must first understand the mechanisms regulating NOS. As such, a brief description of the pathway being examined and the rationale for the experimental strategy are presented before the results.

\section{Calcium}

The most universal stimulator of NOS is calcium, which can act at two sites: first, it can bind calmodulin within the NOS complex to activate the enzyme directly; and second, it can stimulate protein phosphatase 2B, which dephosphorylates NOS at several inhibitory sites (Stuehr 1999). However, there are two confounding side effects: calcium also activates calmodulin-dependent protein kinase II (CaMKII), which phosphorylates and inhibits NOS (Nakane et al. 1991); this is thought to represent feedback inhibition. Calcium can also stimulate protein kinase $\mathrm{C}(\mathrm{PKC})$, which likewise phosphorylates NOS. However, the effects of PKC are controversial, with one group reporting NOS stimulation (Nakane et al. 1991) and others, inhibition (Bredt et al. 1992, Fleming et al. 2001). These potential side effects can be minimized by specific inhibitors. KN-62 is an extremely specific inhibitor of CaMKII: $10 \mu \mathrm{M}$ will completely inhibit CaMKII without significantly affecting any other kinase (Davies et al. 2000).

$\mathrm{PKC}$ is more problematic since there are multiple isoforms, and there are few isozymespecific inhibitors (Hofmann 1997). However, in rats and mice, the major isoforms in the mammary gland are restricted to PKC $\alpha$ and PKCל (Connor \& Clegg 1993, Birkenfeld et al. 1996, Masso-Welch et al. 1999), and PKC $\zeta$ is not activated by calcium. This simplifies the problem and allows the use of a general PKC inhibitor, such as calphostin C, without having to determine which isoform is being affected.

The calcium ionophore, A23187, will elevate intracellular calcium levels, which should activate NOS; the use of KN-62 and calphostin $\mathrm{G}$ should minimize any indirect side effects of the calcium. In contrast, the use of EGTA in combination with A23187 will leach calcium from intracellular stores and sequester it in the external medium; this should suppress the ability of PRL to activate NOS. A scheme displaying the sites of action of these compounds is shown in Fig. 1.

\section{Arginine}

NOS can also be regulated by arginine concentrations, which are limiting in many cells. As such, elevated arginine levels can drive NOS activity (Dodd et al. 2000, Böger \& Bode-Böger 2001). This regulation is facilitated by a physical association between the enzyme and the amino acid transporter, which results in substrate channeling to the enzyme (McDonald et al. 1997). Furthermore, PRL's inhibition of apoptosis in Nb2 cells is due, in part, to arginine-stimulated NO production, suggesting that this is a physiological mechanism of PRL action in some cells (Dodd et al. 2000).

Arginine uptake can be prevented by using arginine-deficient medium or by using competitive inhibitors of the transporter. The transporter used by arginine in the mammary gland is controversial; both the $\mathrm{y}^{+}$and the $\mathrm{b}^{0+}$ systems have been implicated (see the critical discussion in Shennan \& Peaker 2000). As such, both $5 \mathrm{mM}$ lysine and $5 \mathrm{mM}$ glutamine were used to block the $\mathrm{y}^{+}$and $\mathrm{b}^{0+}$ systems respectively (Escobales et al. 2000). It should be noted that there are other ways that cytokines can elevate intracellular arginine concentrations, e.g. by the induction of the genes for arginine synthetase and argininosuccinate lyase and repression of the gene for arginase (Mori \& Gotoh 2000). However, because PRL stimulation of NO production is rapid and brief, the incubation period will only be $15 \mathrm{~min}$, thereby eliminating gene induction/repression as a mechanism for regulating cellular arginine levels.

\section{Other potential mediators}

Finally, it has been shown that PKB can phosphorylate and activate NOS (Dimmeler et al. 


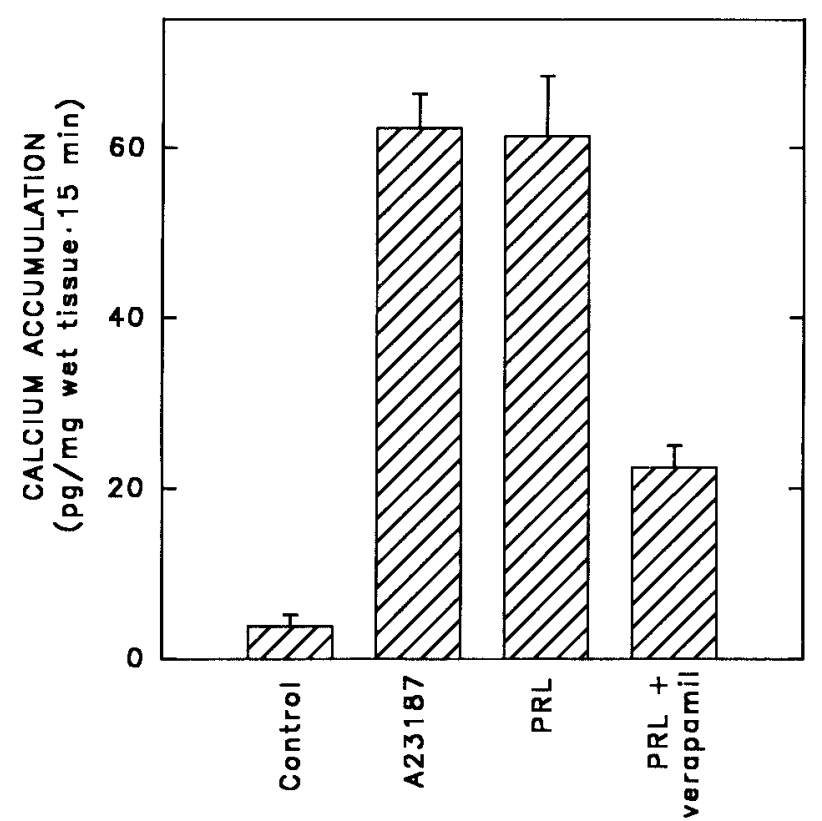

Figure 2 The effect of PRL on calcium accumulation in mammary explants. The tissue was incubated with ${ }^{45} \mathrm{Ca},\left[{ }^{3} \mathrm{H}\right]$ inulin, and either the calcium ionophore, A23187 $(32.5 \mathrm{nM})$, or PRL (100 ng/ml) with or without the calcium channel blocker, verapamil $(30 \mu \mathrm{M})$. After $15 \mathrm{~min}$, the explants were repeatedly washed, solubilized, and counted. Means \pm S.E.S are given for six determinations.

1999, Fulton et al. 1999) and that this is the physiological mechanism by which some hormones stimulate NO production (Radisavljevic et al. 2000). If $\mathrm{PRL}$ activates NOS via $\mathrm{PKB}$ phosphorylation, its effect should be blocked by wortmannin. Wortmannin $(1 \mu \mathrm{M})$ inhibits only phosphatidylinositol 3'-kinase (PI3K), an upstream activator of $\mathrm{PKB}$, and skeletal myosin light chain kinase (Davies et al. 2000); the latter is not found in mammary epithelium. Furthermore, the use of wortmannin to inhibit PI3K has been validated in mammary epithelium (Bolander 1998).

\section{Results}

Figure 2 confirms previous work from this laboratory showing that PRL can rapidly elevate calcium levels in mammary tissue (Bolander 1985). The ability of verapamil to block partially this effect suggests that the calcium is primarily coming from the extracellular medium. Finally, this experiment validates the use of A23187 to raise calcium levels in mammary epithelium.

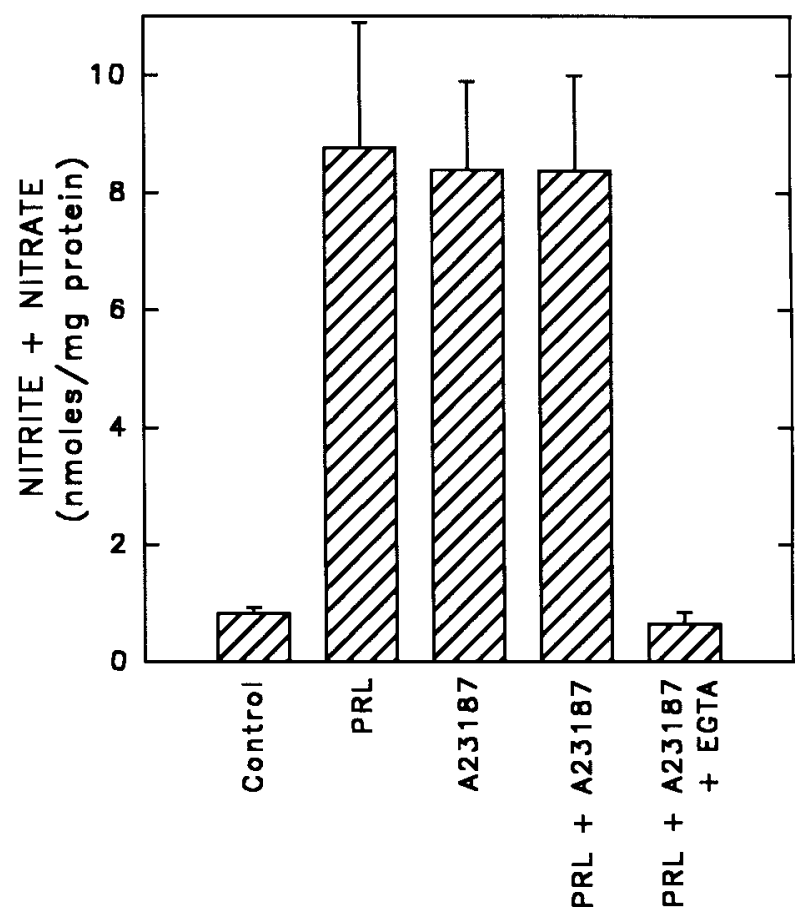

Figure 3 The effect of intracellular calcium elevation or reduction on the ability of PRL to stimulate NO production in mammary epithelial cells. Cells were depleted of intracellular calcium during a 15-min preincubation with the calcium ionophore, A23187 (32.5 nM), and the calcium chelator, EGTA ( $3 \mathrm{mM}$ ). All cultures also contained the CaMKII and PKC inhibitors, KN-62 $(10 \mu \mathrm{M})$ and calphostin $\mathrm{C}(100 \mathrm{nM})$, respectively, during this preincubation. NO production was then determined $15 \mathrm{~min}$ after the addition of PRL (100 ng/ml) and/or A23187 and was estimated from the intracellular nitrite and nitrate levels. Means \pm S.E.S are given for six determinations.

Figure 3 reveals that the elevation of intracellular calcium by the calcium ionophore alone is sufficient to stimulate NO production to a level comparable to that generated by PRL. Furthermore, if A23187 and PRL are using the same mechanism (i.e. calcium), maximal concentrations of each should not be additive; and indeed, this is the case. Finally, the depletion of intracellular calcium through the use of A23187 and EGTA completely prevents the action of PRL.

Figure 4 shows that neither arginine-deficient medium nor inhibitors of the arginine transporters had any effect on the ability of PRL to stimulate NO production at $15 \mathrm{~min}$. Therefore, it would appear that this amino acid is not limiting in the early stages of PRL-stimulated NO production in mammary epithelium. 


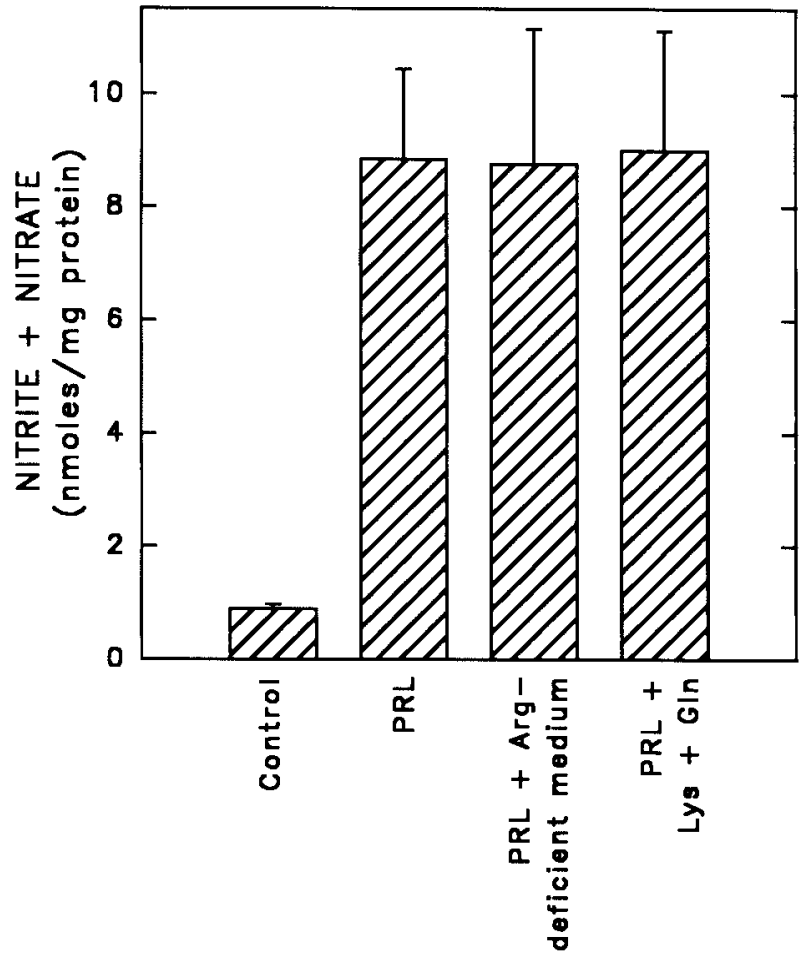

Figure 4 The effect of extracellular arginine (Arg) on the ability of PRL to stimulate NO production in mammary epithelial cells. Cells were pre-incubated for $15 \mathrm{~min}$ in either arginine-deficient medium or with the arginine transport inhibitors, lysine (Lys, $5 \mathrm{mM}$ ) and glutamine (GIn, $5 \mathrm{mM}$ ). NO production was then determined 15 min after the addition of PRL (100 ng/ml) and was estimated from the intracellular nitrite and nitrate levels. Means \pm S.E.S are given for six determinations.

In addition to stimulating NOS directly, calcium can also activate protein phosphatase 2B, which can act indirectly by dephosphorylating NOS at several inhibitory sites. However, cyclosporin A, an inhibitor of protein phosphatase $2 \mathrm{~B}$, had no effect on the acute production of NO by PRL in mammary epithelial cells (Fig. 5). In addition, calcium can stimulate PKC, which may affect NOS positively or negatively, depending upon the system. Figure 3 demonstrated that PKC inhibition did not alter the action of PRL on NO production. In order to test the effects of PKC activation, TPA was used to stimulate this kinase. It should be noted that prolonged exposure to TPA can actually down-regulate PKC; but this was not a problem in these experiments, since the incubation period was only $15 \mathrm{~min}$. Figure 5 shows that PKC activation also had no effect on the action of PRL on NOS.

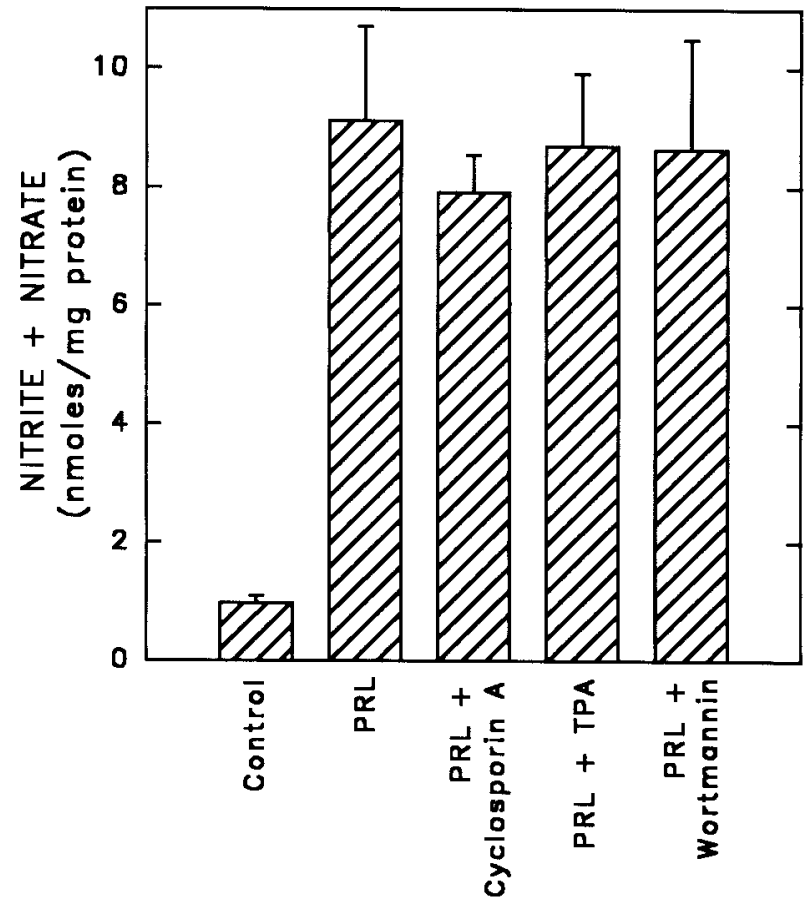

Figure 5 The role of protein phosphatase 2B, PKC and the PI3K pathway in the PRL stimulation of NO production in mammary epithelial cells. Cells were pre-incubated for 15 min with a protein phosphatase $2 B$ inhibitor (cyclosporin A, $100 \mathrm{nM}$ ), a PKC activator (TPA, $1 \mathrm{ng} / \mathrm{ml}$ ), or a PI3K inhibitor (wortmannin, $100 \mathrm{nM}$ ). NO production was then determined 15 min after the addition of PRL $(100 \mathrm{ng} / \mathrm{ml})$ and was estimated from the intracellular nitrite and nitrate levels. Means \pm S.E.S are given for six determinations.

Finally, NOS can be stimulated by PKB phosphorylation. However, inhibition of PI3K, which produces an activator of $\mathrm{PKB}$, did not influence the ability of PRL to stimulate NO production at $15 \mathrm{~min}$ (Fig. 5).

\section{Discussion}

NO, at low concentrations, is an important second messenger; but at high concentrations, it can be toxic. As such, NOS is tightly controlled by multiple regulators, including calcium, phosphorylation, substrate availability, and gene transcription. It is clear from the data in this study that the acute stimulation of NOS by PRL is due to the elevation of intracellular calcium which binds to the calmodulin in the NOS complex. This finding agrees well with a report that the PRL-mediated 
elevation of $\mathrm{NO}$ in mouse macrophages is also calcium-dependent (Kumar et al. 1997). Although the ability of PRL to raise calcium levels in mammary epithelium (Bolander 1985), as well as other tissues (Murphy et al. 1988, Villalba et al. 1991, Ratovondrahona et al. 1998), is well documented, the molecular mechanism responsible for this effect is still unknown. One likely possibility is that the calcium is released by inositol trisphosphate, whose receptor is a calcium channel; this second messenger is known to be elevated by PRL in mammary tissue (Etindi \& Rillema 1988). The inositol trisphosphate, in turn, could be generated by phospholipase $\mathrm{C} \gamma$ activated via Jak-induced tyrosine phosphorylation (Hennighausen et al. 1997, Hynes et al. 1997, Bole-Feysot et al. 1998).

The results from this study do not eliminate the possibility that the other potential regulators examined in these experiments may be important at later time periods. For example, protein phosphatase 2B reverses the effect of CaMKII, whose phosphorylation of NOS is believed to represent negative feedback. As such, it is not likely to have a major impact on NOS activity in quiescent mammary epithelium isolated from virgin mice. However, it may acquire added significance in cells that have already been stimulated. Likewise, intracellular arginine levels appear adequate for the brief, rapid accumulation of NO triggered by PRL; but any subsequent peaks may require the replenishment of intracellular arginine pools, especially since PRL also stimulates polyamine synthesis, which would compete with NOS for this amino acid (Oka et al. 1978). Finally, prolonged or repeated stimulation of this enzyme would probably also affect the transcription of the NOS gene in mammary epithelium.

Prolactin is a member of the cytokine family whose classic output involves the Jak/Stat pathway. However, PRL can also couple to other soluble tyrosine kinases, such as Fyn, Src and Tec (Clevenger \& Medaglia 1994, Berlanga et al. 1995, Kline et al. 2001), to the MAP kinase pathway (Das \& Vonderhaar 1996), the PI3K pathway (Al-Sakkaf et al. 2000, Tessier et al. 2001), and Racl (Kline et al. 2001). Furthermore, the PRL receptor can even directly bind 2',5'-oligoadenylate synthetase (McAveney et al. 2000) and 17 $\alpha$-hydroxysteroid dehydrogenase/17-ketosteroid reductase (Nokelainen et al. 1998). This laboratory has previously reported that NO is another mediator of PRL action in mammary epithelium (Bolander 2001), and this study has delineated the molecular mechanism by which PRL activates the NOS, namely that PRL acutely stimulates NOS by elevating calcium levels.

\section{References}

Alfonso A, Botana MA, Vieytes MR \& Botana LM 2001 Prolactin induces calcium influx and release from intracellular pools in human T lymphocytes by activation of tyrosine kinases. Cellular Signalling 13 819-826.

Al-Sakkaf KA, Mooney LM, Dobson PRM \& Brown BL 2000 Possible role for protein kinase $\mathrm{B}$ in the anti-apoptotic effect of prolactin in rat Nb2 lymphoma cells. Fournal of Endocrinology $\mathbf{1 6 7}$ 85-92.

Berlanga JJ, Angel J, Vara F, Martín-Pérez J \& García-Ruiz JP 1995 Prolactin receptor is associated with c-src kinase in rat liver. Molecular Endocrinology 9 1461-1467.

Birkenfeld HP, McIntyre BS, Briski KP \& Sylvester PW 1996 Protein kinase $\mathrm{C}$ isoenzyme expression in normal mouse mammary epithelial cells grown in primary culture. Proceedings of the Society for Experimental Biology and Medicine 213 65-70.

Böger RH \& Bode-Böger SM 2001 The clinical pharmacology of L-arginine. Annual Review of Pharmacology and Toxicology 41 79-99.

Bolander FF 1985 Possible roles of calcium and calmodulin in mammary gland differentiation in vitro. Journal of Endocrinology $\mathbf{1 0 4}$ 29-34.

Bolander FF 1998 Transduction pathways involved in rapid hormone receptor regulation in the mammary epithelium. American fournal of Physiology 275 E553-E557.

Bolander FF 2001 The role of nitric oxide in the biological activity of prolactin in the mouse mammary gland. Molecular and Cellular Endocrinology 174 91-98.

Bole-Feysot C, Goffin V, Edery M, Binart N \& Kelly PA 1998 Prolactin (PRL) and its receptor: actions, signal transduction pathways and phenotypes observed in PRL receptor knockout mice. Endocrine Reviews 19 225-268.

Bredt DS, Ferris CD \& Snyder SH 1992 Nitric oxide synthase regulatory sites: phosphorylation by cyclic AMP-dependent protein kinase, protein kinase $\mathrm{C}$, and calcium/calmodulin protein kinase; identification of flavin and calmodulin binding sites. Fournal of Biological Chemistry 267 10976-10981.

Caulfield JJ \& Bolander FF 1986 Involvement of protein kinase C in mouse mammary gland development. Fournal of Endocrinology 109 29-34.

Clevenger CV \& Medaglia MV 1994 The protein tyrosine kinase p5 $59^{\mathrm{fyn}}$ is associated with prolactin (PRL) receptor and is activated by PRL stimulation of T-lymphocytes. Molecular Endocrinology 8 $674-681$.

Connor K \& Clegg RA 1993 Isoenzymes of protein kinase C in rat mammary tissue: changes in properties and relative amounts during pregnancy and lactation. Biochemical fournal 291 817-824.

Das R \& Vonderhaar BK 1996 Activation of Raf-1, MEK, and MAP kinase in prolactin responsive mammary cells. Breast Cancer Research and Treatment 40 141-149.

Davies SP, Reddy H, Caivano M \& Cohen P 2000 Specificity and mechanism of action of some commonly used protein kinase inhibitors. Biochemical foumal 351 95-105.

Dimmeler S, Fleming I, Fisslthaler B, Hermann C, Busse R \& Zeiher AM 1999 Activation of nitric oxide synthase in endothelial cells by Akt-dependent phosphorylation. Nature 399 601-605. 
Dodd F, Limoges M, Boudreau RTM, Rowden G, Murphy PR \& Too CKL 2000 L-Arginine inhibits apoptosis via a NO-dependent mechanism in Nb2 lymphoma cells. Fournal of Cellular Biochemistry $77624-634$.

Escobales N, Rivera-Correa M, Altieri PI \& Rodriguez JF 2000 Relationship between NO synthesis, arginine transport, and intracellular arginine levels in vascular smooth muscle cells. Amino Acids 19 451-468.

Etindi RN \& Rillema JA 1988 Prolactin induces the formation of inositol bisphosphate and inositol trisphosphate in cultured mouse mammary gland explants. Biochimica et Biophysica Acta 968 385-391.

Fleming I, Fisslthaler B, Dimmeler S, Kemp BE \& Busse R 2001 Phosphorylation of $\mathrm{Thr}^{495}$ regulates $\mathrm{Ca}^{2+}$ /calmodulin-dependent endothelial nitric oxide synthase activity. Circulation Research $\mathbf{8 8}$ E68-E75.

Fulton D, Gratton JP, McCabe TJ, Fontana J, Fujio Y, Walsh K Franke TF, Papapetropoulos A \& Sessa WC 1999 Regulation of endothelium-derived nitric oxide production by the protein kinase Akt. Nature 399 597-601.

Hennighausen L, Robinson GW, Wagner KU \& Liu X 1997 Prolactin signaling in mammary gland development. Fournal of Biological Chemistry 272 7567-7569.

Hofmann J 1997 The potential for isoenzyme-selective modulation of protein kinase C. FASEB Fournal 11 649-669.

Hynes NE, Cella N \& Wartmann M 1997 Prolactin mediated intracellular signaling in mammary epithelial cells. Fournal of Mammary Gland Biology and Neoplasia 2 19-27.

Kline JB, Moore DJ \& Clevenger CV 2001 Activation and association of the Tec tyrosine kinase with the human prolactin receptor: mapping of a Tec/Vavl-receptor binding site. Molecular Endocrinology 15 832-841.

Kumar A, Singh SM \& Sodhi A 1997 Effect of prolactin on nitric oxide and interleukin-1 production of murine peritoneal macrophages: role of $\mathrm{Ca}^{2+}$ and protein kinase C. International Fournal of Immunopharmacology 19 129-133.

Lowry OH, Rosebrough NJ, Farr AL \& Randall RJ 1951 Protein determination with the Folin phenol reagent. Fournal of Biological Chemistry 193 265-275.

Martel P, Houdebine LM, Teyssot B \& Djiane J 1983 Effects of phorbol esters on multiplication and differentiation of mammary cells. Biology of the Cell 49 119-126.

Masso-Welch PA, Verstovsek G \& Ip MM 1999 Alterations in the expression and localization of protein kinase $\mathrm{C}$ isoforms during mammary gland differentiation. European Fournal of Cell Biology $\mathbf{7 8}$ 497-510.

McAveney KM, Book ML, Ling P, Chebath J \& Yu-Lee L 2000 Association of $2^{\prime}, 5^{\prime}$-oligoadenylate synthetase with the prolactin (PRL) receptor: alteration in PRL-inducible Statl (signal transducer and activator of transcription 1) signaling to the IRF-1 (interferon-regulatory factor 1) promoter. Molecular Endocrinology 14 295-306.

McDonald KK, Zarikov S, Block ER \& Kilberg MS 1997 A caveolar complex between the cationic amino acid transporter 1 and endothelial nitric-oxide synthase may explain the 'arginine paradox'. Fournal of Biological Chemistry 272 31213-31216.

Mori M \& Gotoh T 2000 Regulation of nitric oxide production by arginine metabolic enzymes. Biochemical and Biophysical Research Communications 275 715-719.

Murphy PR, Dimattia GE \& Friesen HG 1988 Role of calcium in prolactin-stimulated c-myc gene expression and mitogenesis in NB2 lymphoma cells. Endocrinology 122 2476-2485.

Nakane M, Mitchell J, Förstermann U \& Murad F 1991 Phosphorylation by calcium calmodulin-dependent protein kinase II and protein kinase $\mathrm{C}$ modulates the activity of nitric oxide synthase. Biochemical and Biophysical Research Communications $\mathbf{1 8 0}$ 1396-1402.

Nokelainen P, Peltoketo H, Vihko R \& Vihko P 1998 Expression cloning of a novel estrogenic mouse $17 \alpha$-hydroxysteroid dehydrogenase/17-ketosteroid reductase (m17 HSD7), previously described as a prolactin receptor-associated protein (PRAP) in rat. Molecular Endocrinology 12 1048-1059.

Oka T, Sakai T, Lundgren DW \& Perry JW 1978 Polyamines in growth and development of mammary gland. In Hormones, Receptors, and Breast Cancer, pp 301-323. Ed WL McGuire. New York: Raven Press.

Radisavljevic Z, Avraham H \& Avraham S 2000 Vascular endothelial growth factor up-regulates ICAM-1 expression via the phosphatidylinositol $3 \mathrm{OH}$-kinase/AKT/nitric oxide pathway and modulates migration of brain microvascular endothelial cells. Fournal of Biological Chemistry 275 20770-20774.

Ratovondrahona D, Fahmi M, Fournier B, Odessa MF, Skryma R, Prevarskaya N, Djiane J \& Dufy B 1998 Prolactin induces an inward current through voltage-independent $\mathrm{Ca}^{2+}$ channels in Chinese hamster ovary cells stably expressing prolactin receptor. Fournal of Molecular Endocrinology 21 85-95.

Rillema JA, Golden K \& Jenkins MA 1992 Effect of prolactin on $\alpha$-aminoisobutyric acid uptake in mouse mammary gland explants. American Fournal of Physiology 262 E402-E405.

Shennan DB \& Peaker M 2000 Transport of milk constituents by the mammary gland. Physiological Reviewes 80 925-951.

Stuehr DJ 1999 Mammalian nitric oxide synthases. Biochimica et Biophysica Acta 1411 217-230.

Tessier C, Prigent-Tessier A, Ferguson-Gottschall S, Gu Y \& Gibori G 2001 PRL antiapoptotic effect in the rat decidua involves the $\mathrm{PI} 3 \mathrm{~K} /$ protein kinase B-mediated inhibition of the caspase-3 activity. Endocrinology 142 4086-4094.

Villalba M, Zabala MT, Martinez-Serrano A, de la Colina R, Satrústegui J \& Garcia-Ruiz JP 1991 Prolactin increases cytosolic free calcium concentration in hepatocytes of lactating rats. Endocrinology 129 2857-2861.

Vonderhaar BK, Owens IS \& Topper YJ 1973 An early effect of prolactin on the formation of $\alpha$-lactalbumin by mouse mammary epithelial cells. Fournal of Biological Chemistry $\mathbf{2 4 8}$ $467-471$.

Received 22 October 2001 Accepted 20 November 2001 